\title{
PENERAPAN AUTOREGRESSIVE DISTRIBUTED LAG DALAM MEMODELKAN PENGARUH INFLASI, PERTUMBUHAN EKONOMI, DAN FDI TERHADAP PENGANGGURAN DI INDONESIA
}

\author{
Jumhur* \\ Universitas Tanjungpura, Indonesia
}

\begin{abstract}
This study aims to examine the effect of inflation, economic growth, and foreign investment on unemployment in Indonesia. Using the autoregressive distributed lag (ARDL) analysis method to analyze the 1991-2018 time series data collected from the World Bank's World Development Indicators database. The results found that inflation has a negative and significant effect in the short term but not significant in the long term in Indonesia. Economic growth has a negative and significant effect on both short and long-term unemployment in Indonesia, and foreign investment has a negative and significant effect on both short and long-term unemployment in Indonesia. Through the ARDL model, this research is able to prove that inflation, economic growth, foreign investment, and budgeting are proven to have long-term cointegration or move together in the long term. The four variables also have a dynamic short-term relationship that has a fairly high speed of adjustment towards equilibrium per year. Based on the results, policymakers, in this case the government must provide a conducive investment environment by eliminating the structural rigidity that exists in the economy to attract investment, both foreign and domestic investment, to encourage economic growth and create jobs in Indonesia.
\end{abstract}

JEL: B22, E22

Keywords : unemployment, inflation, economic growth, foreign direct investment.

\begin{abstract}
ABSTRAK
Penelitian ini bertujuan untuk menguji pengaruh inflasi, pertumbuhan ekonomi, dan penanaman modal asing terhadap pengangguran di Indonesia. Menggunakan metode analisis autoregressive distributed lag (ARDL) untuk menganalisis data time series periode 1991-2018 yang dikumpulkan dari database World Development Indicators Bank Dunia. Hasil penelitian menemukan inflasi berpengaruh negatif dan signifikan dalam jangka pendek namun tidak signifikan dalam jangka panjang di Indonesia. Pertumbuhan ekonomi berpengaruh negatif dan signifikan baik jangka pendek maupun jangka panjang terhadap pengangguran di Indonesia dan penanaman modal asing berpengaruh negatif dan signifikan baik jangka pendek maupun jangka panjang terhadap pengangguran di Indonesia. Melalui model ARDL, penelitian ini mampu membuktikan inflasi, pertumbuhan ekonomi, penanaman modal asing, dan penganggaran terbukti memiliki kointegrasi jangka panjang atau bergerak bersama-sama dalam jangka panjang. Keempat variabel tersebut juga mempunyai dinamika hubungan jangka pendek yang mempunyai kecepatan penyesuaian menuju keseimbangan yang cukup tinggi pertahunnya. Berdasarkan hasil penelitian, maka pengambil kebijakan, dalam hal ini pemerintah harus menyediakan lingkungan investasi yang kondusif dengan menghilangkan kekakuan struktural yang ada dalam perekonomian untuk menarik investasi baik investasi asing maupun investasi dalam negeri untuk mendorong pertumbuhan ekonomi dan menciptakan lapangan kerja di Indonesia.
\end{abstract}

Kata Kunci : pengangguran, inflasi, pertumbuhan ekonomi, penanaman modal asing langsung.

\footnotetext{
*Email : jumhurie@yahoo.com

Received : 12-07-2020, Accepted: 25-12-2020, Published : 28-12-2020

P-ISSN : 2087-9954, E-ISSN : 2550-0066. DOI : http://dx.doi.org/10.26418/jebik.v9vi3.41332
} 


\section{PENDAHULUAN}

Pengangguran merupakan fenomena multidimensi yang mengiringi fenomena ekonomi dan sosial yang menunjukkan perbedaan dalam kegiatan ekonomi yang akan membawa konsekuensi pada sebagai aktivitas sosial masyarakat (Al-Habees \& Rumman, 2012). Misalnya, dampak sosial pengangguran dapat berupa depresi, kurangnya harga diri, dan kejahatan lain seperti perampokan, pelacuran dan sebagainya (Adarkwa, 2017). Dampak ekonomi dari hal tersebut dapat menghalangi negara memperoleh pendapatan pajak penghasilan, pemborosan jam produktif, dan banyak dampak lainnya (Seth, John, \& Dalhatu, 2018). Organisasi Perburuhan Internasional (ILO) mendefinisikan pengangguran berdasarkan tiga kondisi penting yang harus dipenuhi secara bersamaan dan kondisi-kondisi ini adalah tidak bekerja, siap untuk dipekerjakan, dan mencari pekerjaan (ILO, 2019).

Para ekonom telah mengajukan berbagai alternatif teori untuk menjelaskan fenomena terjadinya pengangguran guna membantu mencari solusi mengatasinya. Teori-teori klasik menjelaskan bahwa pengangguran merupakan masalah permintaan dan penawaran jangka pendek, dan kekuatan pasar bebas akan secara otomatis mengatasinya sehingga kesempatan kerja penuh akan selalu tercipta dalam perekonomian (Pigou, 1934). Teori keynesian berpandangan bahwa pengangguran biasanya dipicu oleh berkurangnya permintaan agregat selama periode tertentu dalam pasar tenaga kerja sehingga mengurangi lapangan kerja yang memadai untuk mengakomodasi orang yang ingin bekerja (Keynes, 1936). Disisi lain, hukum Okun adalah satusatunya model ekonomi yang hanya berfokus pada hubungan pertumbuhan ekonomi dengan pengangguran (Okun, 1962). Jadi menurut teori-teori ini, pengangguran dapat terjadi karena satu atau beberapa variabel dalam sebuah perekonomian.

Tingkat inflasi dan pengangguran yang rendah adalah tujuan utama kebijakan ekonomi makro baik di negara berkembang maupun negara maju, meskipun hipotesis kurva menunjukkan bahwa ada hubungan trade-off antara inflasi dan pengangguran (Phillips, 1958). Walaupun sejumlah hasil studi berpendapat bahwa trade-off ini hanya ada dalam jangka pendek, tapi tidak dalam jangka panjang (Friedman, 1968). Investasi asing (foreign direct investment/FDI) adalah salah satu komponen kunci dari sistem ekonomi internasional yang terbuka dan efisien. FDI adalah investasi langsung yang dilakukan oleh individu atau perusahaan di negara lain untuk kepentingan produksi atau bisnis, baik dengan secara langsung membangun bisnis atau memperluas operasi bisnis yang sudah ada atau dengan membeli perusahaan di negara sasaran (Johnny, Timipere, \& Krokeme, 2018). Untuk membuktikan secara empiris pengaruh FDI terhadap pengangguran diantaranya telah dilakukan oleh Stamatiou dan Dritsakis (2014) yang menggunakan beberapa model ekonometrik untuk mengevaluasi dampak FDI terhadap pengangguran dan pertumbuhan ekonomi di Yunani tahun 1970 hingga 2012. Hasil yang ditemukan yaitu dalam jangka pendek dan jangka panjang FDI mengurangi pengangguran di negara tersebut. Sedangkan hasil empiris di Indonesia diantaranya telah dilakukan oleh Tegep, Suratman, dan Indra (2019) yang menemukan FDI tidak berpengaruh signifikan pada pengangguran.

Perkembangan tingkat pengangguran, inflasi, FDI serta Pertumbuhan Ekonomi di Indonesia tahun 1991-2018 fluktuatif seperti terlihat pada Gambar 1 berikut ini. 

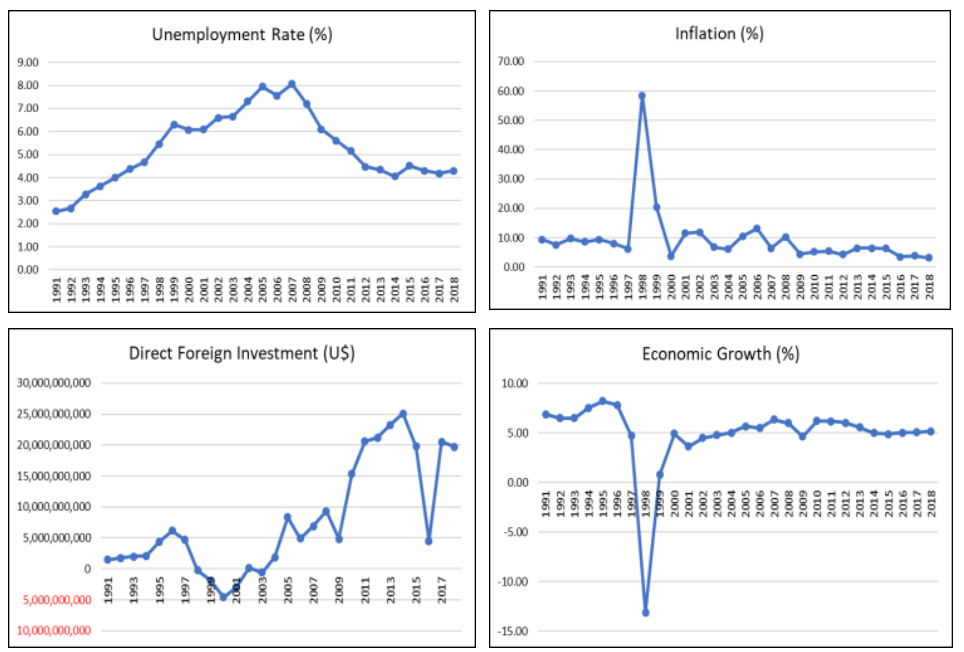

\section{Gambar 1. Tingkat Pengangguran, Inflasi, FDI dan Pertumbuhan Ekonomi Indonesia Tahun 1991-2018 \\ (Sumber: Database World Development Indicators Bank Dunia)}

Berdasarkan beberapa fenomena yang telah dijelaskan diatas, penelitian ini ingin membahas lebih lanjut mengenai pengaruh inflasi, pertumbuhan ekonomi, dan penanaman modal asing langsung terhadap pengangguran di Indonesia. Menggunakan pendekatan autoregressive distributed lag (ARDL) yang memodelkan fungsi tersebut untuk memperoleh gambaran yang lebih komprehensif dalam memahami pengaruh inflasi, pertumbuhan ekonomi, dan FDI terhadap pengangguran, tidak hanya dalam jangka pendek, tapi juga dalam jangka panjang (dinamis) untuk perekonomian Indonesia periode tahun 1991-2018.

\section{KAJIAN LITERATUR}

Pengangguran adalah salah satu indikator aktivitas ekonomi makro yang paling terlihat (Parker, 2010). Tingkat pengangguran biasanya meningkat secara signifikan selama resesi kemudian turun ketika ekonomi pulih. Sebagian besar pengangguran di negara berkembang maupun negara maju disebabkan adanya pendatang baru di pasar tenaga kerja yang mencari pekerjaan pertama, orang-orang yang secara sukarela berganti pekerjaan, dan orang-orang yang di PHK dalam pekerjaan (Parker, 2010). Teori klasik, seperti yang dianalisis oleh Pigou (1934) berpendapat bahwa pasar tenaga kerja terdiri dari permintaan dan penawaran tenaga kerja. Permintaan tenaga kerja adalah permintaan turunan yang diperoleh dari bagian yang menurun dari produk marginal tenaga kerja. Kurva permintaan adalah fungsi negatif dari upah riil karena jika upah meningkat maka permintaan jumlah tenaga kerja akan menurun dan yang terjadi adalah sebaliknya. Sementara Keynes (1936) menganggap pengangguran sebagai fenomena yang tidak disengaja dan dia berpikir bahwa lapangan kerja adalah siklus yang disebabkan oleh kekurangan permintaan agregat. Konsisten dengan pengajaran Keynes, seorang perwakilan ekonomi Post Keynesian, berpendapat bahwa pengangguran tidak sukarela dijelaskan oleh kurangnya permintaan yang efektif, ketidakstabilan dari nilai tukar, dan mobilitas keuangan internasional dimana menciptakan ketidakpastian yang melemahkan kepercayaan wirausaha untuk melakukan investasi untuk mengurangi pengangguran (Davidson, 1998).

Hubungan antara pertumbuhan ekonomi dan pengangguran pertama kali dikonseptualisasikan oleh Okun. Hukum Okun menyatakan bahwa peningkatan pertumbuhan 
ekonomi berarti penurunan tingkat pengangguran. Okun memberikan gagasan umum yang menafsirkan bahwa ketika pengangguran turun, produksi suatu negara akan meningkat. Ukuran ini dapat digunakan untuk memperkirakan GNP dan PDB. Sedangkan hubungan antara inflasi dan pengangguran digambarkan oleh kurva Phillips. Kurva Phillips menggambarkan kemiringan negatif kurva yang menunjukkan hubungan antara dua variabel yang berbanding terbalik. Ini diprakarsai oleh Phillips (1958) yang menemukan bahwa tingkat perubahan upah nominal memiliki korelasi negatif dengan tingkat pengangguran di Inggris.

Proyek-proyek yang didanai oleh investor asing menghasilkan lebih banyak pasar kerja untuk tenaga kerja terampil dan tidak terampil. Ini seharusnya mengurangi tingkat pengangguran (Pinn, Ching, Kogid, Mulok, Mansur, \& Loganathan, 2011; Zeb, Qiang, \& Sharif, 2014). Kontributor terkemuka untuk literatur ini adalah Davidson \& Matusz (2004) untuk pekerjaan representatif dan survei, dan ada juga Moore \& Ranjan (2005) serta Mitra \& Ranjan (2010) untuk kontribusi terbaru pada literatur ini. Sebagian besar literatur ini bersifat teoritis. Kontribusi terbaru berdasarkan analisis lintas negara dan yang menggabungkan pengalaman negara berkembang adalah Dutt, Mitra, \& Ranjan (2009). Sejumlah ahli berpendapat bahwa negara-negara dengan tingkat pengangguran yang lebih tinggi memiliki dua utama keuntungan di mata investor asing: (a) banyak tenaga kerja yang tersedia; (b) probabilitas tinggi untuk menemukan tenaga kerja yang tersedia dengan upah lebih rendah (Barens, 2011). Namun, teori lain menunjukkan bahwa tingkat pengangguran yang terlalu tinggi yang dicatat di suatu negara dianggap oleh investor asing sebagai sinyal disequilibrium ekonomi makro, sehingga negara tersebut tidak dipandang sebagai negara tuan rumah yang tepat untuk investasi masa depan (Brozen, 1958).

\subsection{Pengaruh Inflasi terhadap Pengangguran}

Inflasi dan pengangguran adalah masalah yang paling kritis di banyak negara. Variabelvariabel tersebut memiliki konsekuensi terhadap berbagai kegiatan ekonomi seperti tabungan, ekspor investasi, kemiskinan, pertumbuhan ekonomi, dan sebagainya (Yolanda, 2017; Behera \& Mishra, 2017). Para peneliti telah menyelidiki hubungan antara inflasi dan pengangguran (kurva Phillips) dari waktu ke waktu, misalnya menggunakan penduga efek tetap dan acak termasuk kointegrasi dan uji kausalitas Granger untuk menguji hubungan jangka panjang antara inflasi dan pengangguran di Indonesia (Bhattarai, 2016). Orji, Orji, dan Okafor (2015) menyelidiki keberadaan kurva Phillips di Nigeria dari 1970 hingga 2011 menggunakan pendekatan pengujian batas ARDL. Bukti empiris menunjukkan bahwa pengangguran memiliki efek positif dan signifikan terhadap inflasi, dan dengan demikian membatalkan proposal kurva Phillips untuk Nigeria. Studi ini dimaksudkan untuk menguji hubungan antara inflasi dan tingkat pengangguran di Indonesia selama periode 1987 hingga 2018 menggunakan metode kuantitatif vector error correction model (VECM). Temuan menunjukkan bahwa inflasi memiliki hubungan satu arah dengan pengangguran di Indonesia (Wulandari, Utomo, Narmaditya, \& Kamaludin, 2019).

\subsection{Pengaruh Pertumbuhan Ekonomi terhadap Pengangguran}

Dampak pertumbuhan ekonomi terhadap pengangguran berbeda di setiap negara tergantung pada struktur pasar tenaga kerja dan periode yang dipertimbangkan. Misalnya, di negara-negara Arab dari 1994 hingga 2010, peningkatan 1 persen dalam tingkat pertumbuhan ekonomi menurunkan tingkat pengangguran sebesar 0,16 persen (Kunle, \& Oluwafolakemi, 2014). Untuk ekonomi India dari 2009 hingga 2015, ada trade-off jangka pendek antara pengangguran terhadap PDB riil sangat minim (Singh \& Verma, 2016). Di tingkat provinsi di Vietnam, investasi 
publik ditemukan berkorelasi positif dengan pertumbuhan ekonomi, tetapi dampak pengurangan pengangguran bergantung pada efisiensi investasi (Quy, 2016).

Amor \& Hassine (2017) menyimpulkan bahwa hubungan jangka panjang antara tingkat pertumbuhan PDB riil dan tingkat pengangguran mendukung koefisien negatif Okun karena pertumbuhan ekonomi yang luar biasa selama 30 tahun terakhir untuk Kerajaan Arab Saudi. Namun, dalam jangka pendek, hukum pengangguran Okun, hubungan output tidak menunjukkan hasil yang signifikan. Selain itu, Tenzin (2019) menggunakan model ARDL untuk memahami dampak pertumbuhan ekonomi terhadap pengangguran di Bhutan dan menemukan bahwa pertumbuhan ekonomi tidak berdampak pada pengurangan tingkat pengangguran di Bhutan baik dalam jangka pendek maupun jangka panjang.

\subsection{Pengaruh FDI Terhadap Pengangguran}

Banyak peneliti meneliti hubungan antara FDI dan pengangguran. Beberapa peneliti mempertimbangkan efek dalam ekonomi spesifik (satu ekonomi tunggal), sementara yang lain menggunakan regresi panel untuk beberapa negara. Irpan, Saad, Nor, Noor, \& Ibrahim (2016) menguji dampak FDI pada tingkat pengangguran di Malaysia. Model autoregressive distributed lag (ARDL) digunakan untuk menentukan hubungan jangka panjang antara variabel. Studi ini menemukan bahwa FDI, jumlah pekerja asing, dan PDB secara signifikan mempengaruhi tingkat pengangguran di Malaysia. Stamatiou \& Dritsakis (2014) menggunakan beberapa model ekonometrik untuk mengevaluasi dampak FDI terhadap pengangguran dan pertumbuhan ekonomi di Yunani.

Analisis persamaan FDI dalam jangka pendek dan jangka panjang menunjukkan bahwa peningkatan FDI akan meningkatkan pertumbuhan dan akan mengurangi pengangguran. Menurut hasil regresi hipotesis bahwa FDI memiliki dampak positif dan secara statistik penting untuk mengurangi pengangguran di Republik Makedonia tidak dapat dikonfirmasi (Djambaska \& Lozanoska, 2015). Strat, Davidescu, dan Paul (2015) menyelidiki saling ketergantungan antara FDI dan pengangguran, dan menemukan dalam kasus 4 dari 13 anggota UE terbaru-Hongaria, Malta, Bulgaria, dan Estonia, ada hubungan kausal antara FDI dan pengangguran. Namun, hubungan yang berlawanan telah dikonfirmasi dalam kasus Rumania, Republik Ceko dan Slovakia, yang berarti bahwa investor asing mempertimbangkan lokasi dimana terdapat banyak tenaga kerja yang tersedia. Tidak adanya pengurangan pengangguran di kedua negara ini terjadi karena fakta bahwa kedua negara menarik sebagian besar FDI dalam bentuk merger dan akuisisi serta usaha patungan (Kurtovic, Siljkovic, \& Milanovic, 2015).

Dari penjelasan di atas dapat digambarkan pengaruh inflasi, pertumbuhan ekonomi, dan FDI terhadap pengangguran di Indonesia dalam suatu kerangka pemikiran penelitian seperti berikut. 


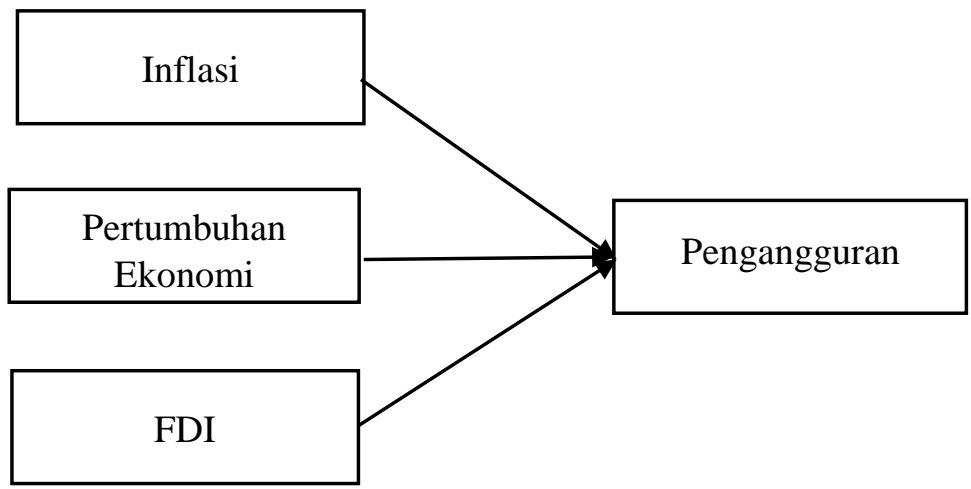

Gambar 2. Kerangka Konseptual

Berdasarkan kerangka konseptual di atas, maka hipotesis penelitian ini adalah:

1. Inflasi berpengaruh signifikan terhadap pengangguran di Indonesia.

2. Pertumbuhan Ekonomi berpengaruh signifikan terhadap pengangguran di Indonesia.

3. FDI berpengaruh signifikan terhadap pengangguran di Indonesia.

\section{METODE PENELITIAN}

Penelitian ini menggunakan data sekunder yang bersifat tahunan dalam bentuk data time series periode tahun 1991-2018. Semua data seperti pengangguran, inflasi, pertumbuhan ekonomi, serta FDI diperoleh dari database World Development Indicators (WDI) Bank Dunia. Pertumbuhan ekonomi diproksi dengan persentasi pertumbuhan PDB per tahun dengan jumlah nilai tambah yang dihasilkan oleh semua produsen yang tinggal dalam perekonomian dalam satuan persentase. Pengangguran diproksi dengan total pengangguran yaitu persentase dari total angkatan kerja yang mengacu pada bagian angkatan kerja yang tidak bekerja tetapi tersedia untuk bekerja dan mencari pekerjaan. Inflasi diproksi dengan inflasi harga konsumen yang diukur dengan indeks harga konsumen dimana mencerminkan persentase perubahan tahunan biaya terhadap rata-rata konsumen dalam memperoleh sejumlah barang dan jasa. Investasi asing langsung (FDI) diproksi dengan jumlah arus masuk neto yaitu investasi asing langsung mengacu pada aliran ekuitas investasi langsung dalam perekonomian Indonesia.

Metode yang digunakan adalah autoregressive distributed lag (ARDL) yang merupakan model dinamis dalam ekonometrika karena menggambarkan alur waktu dalam variabel dependen dalam hubungannya dengan nilai pada waktu lampau. ARDL adalah gabungan antara metode autoregressive (AR) dan distributed lag (DL). Lag berarti bahwa suatu nilai masa lalu yang akan digunakan untuk melihat nilai masa depan. Metode AR adalah metode yang menggunakan satu atau lebih data masa lampau dari variabel dependen, sedangkan DL adalah metode regresi yang melibatkan data pada waktu sekarang dan waktu lampau dari variabel independen. Model ini dapat membedakan respon jangka pendek dan jangka panjang dari variabel yang diteliti. Berikut merupakan keunggulan model ARDL: (a) ARDL tidak mementingkan tingkat stasioner data pada ordo yang sama, akan tetapi metode ini tidak bisa digunakan apabila data yang digunakan stasioner pada tingkat 2 difference; (b) ARDL tidak mempermasalahkan jumlah sampel atau observasi yang sedikit. 
Dengan menggunakan ARDL dapat diperoleh estimasi jangka panjang dan estimasi jangka pendek secara serentak, yang akan menghindarkan terjadinya masalah autokorelasi. Adapun model umum dari ARDL adalah sebagai berikut:

$\Delta Y_{t}=\beta_{0}+\sum_{i=1}^{n} \beta_{1} \Delta Y_{t-1}+\sum_{i=0}^{n} \Delta X_{t-1}+\varphi_{1} y_{t-1}+\varphi_{2} x_{t-1}+\mu_{t}$

Dimana:

$B_{1}, \beta_{2}=$ koefisien jangka pendek,

$\varphi_{1,} \varphi_{1} \quad=$ koefisien ARDL jangka panjang,

$\mu_{t} \quad=$ disturbance error.

Keunggulan ARDL adalah kemampuannya mendeteksi dinamika jangka panjang maupun jangka pendek. Berdasarkan model umum ARDL pada persamaan (1) yang merupakan merupakan persamaan hubungan jangka pendek:

$\sum_{i=1}^{n} \beta_{1} \Delta Y_{1-t}+\sum_{i-0}^{n} \beta_{2} \Delta X_{t-1}$

Adapun untuk hubungan jangka panjang ditunjukkan dengan persamaan:

$\varphi_{1} y_{t-1}+\varphi_{2} x_{t-1}$

Berdasarkan paparan di atas persamaan ARDL yang digunakan pada penelitian ini adalah:

$$
\begin{aligned}
\Delta U N E M P_{t}= & \beta+\beta_{1} \sum_{i=1}^{p} \Delta U N E M P_{t-1}+\beta_{2} \sum_{i=1}^{P} \Delta I N F L_{t-i}+\beta_{3} \sum_{i-1}^{p} \Delta G R O W T H_{t-1}+ \\
& \beta_{4} \sum_{I=1}^{P} \Delta F D I_{t-I}+\beta_{5} \Delta I N F L_{t-1}+\beta_{6} \Delta G R U W T H_{t-1}+\beta_{7} \Delta F D I_{t-1}+\varepsilon_{t . .}
\end{aligned}
$$

Dimana:

UNEMP = variabel pengangguran,

INFL $\quad=$ variabel inflasi,

GROWTH = variabel pertumbuhan ekonomi,

FDI $\quad=$ variabel penanaman modal asing di Indonesia,

$\beta_{1}, \beta_{2}, \beta_{3}, \beta_{4}=$ dinamika jangka pendek dari model,

$\beta_{5}, \beta_{6}$, dan $\beta_{7}=$ hubungan jangka panjang dari model penelitian,

$\Delta \quad=$ selisih (perubahan) antara dua nilai suatu variabel dalam periode waktu yang berurutan,

$\varepsilon \quad=$ error yang terdistribusi normal.

Adapun langkah-langkah analisis data dengan menggunakan pendekatan ARDL, dalam penelitian ini adalah sebagai berikut : (1) sebelum melakukan regresi dengan menggunakan data time series, perlu dilakukan uji stasioneritas pada seluruh variabel untuk mengetahui variabel tersebut stasioner atau tidak. Uji stasioneritas dalam penelitian ini menggunakan augmented dickey-fuller (ADF) atau unit root test; (2) melakukan pemilihan model ARDL yang akan digunakan sebagai dasar estimasi koefisien jangka panjang dan jangka pendek. Model ARDL yang dipilih berdasarkan schwarz bayesian criterion (SBC) yang mampu memilih panjang lag terkecil atau berdasarkan akaike information criterion (AIC) untuk memilih panjang lag maksimal yang relevan; (3) melakukan pengujian kesesuaian model ARDL yang dipilih; (4) untuk menguji stabilitas neraca transaksi berjalan digunakan CUSUM (cumulative sum of recursive residuals). 
Jika plot CUSUM berada pada nilai kritis 5 persen atau tidak keluar dari garis batas atas dan batas bawah, maka estimasi dianggap stabil, begitu pula sebaliknya. Selain CUSUM test, digunakan pula CUSUMQ atau cumulative sum of squares of recursive residuals yang berlaku sama seperti CUSUM test; (5) bounds test, dimana uji ini dilakukan untuk mengetahui keberadaan hubungan jangka panjang (kointegrasi) dan kausalitas antara variabel yang dipergunakan dalam model.

\section{HASIL DAN PEMBAHASAN}

Berdasarkan hasil uji unit root pada Tabel 1 dengan ADF, hanya dua variabel yang stasioner pada tingkat level yaitu pertumbuhan ekonomi dan inflasi yang ditunjukkan dengan probabilitas lebih kecil dari 5\%. Sedangkan dua variabel yang stasioner pada first difference yaitu variabel FDI dan pertumbuhan ekonomi yang ditunjukkan dengan probabilitas lebih kecil dari 5\%. Berdasarkan hasil uji stasioneritas yang diperoleh bahwa tidak ada variabel yang stasioner pada tingkat second diff, sehingga model autoregressive distributed lag (ARDL) layak digunakan.

Tabel 1. Hasil Uji Unit Akar

Uji Unit Akar pada Tingkat Level

\begin{tabular}{ccccc}
\hline Series & Prob. & Lag & Max Lag & Obs \\
\hline FDI & 0.1632 & 0 & 5 & 27 \\
GROWTH & $0.0091^{*}$ & 0 & 5 & 27 \\
INFL & $0.0032^{*}$ & 0 & 5 & 27 \\
UNEMP & 0.3193 & 1 & 5 & 26 \\
\hline
\end{tabular}

Uji Unit Akar pada Tingkat First Difference

\begin{tabular}{ccccc}
\hline Series & Prob. & Lag & Max Lag & Obs \\
\hline D(FDI) & $0.0001^{*}$ & 2 & 5 & 24 \\
D(GROWTH) & $0.0000^{*}$ & 0 & 5 & 26 \\
D(INFL) & $0.0000^{*}$ & 1 & 5 & 25 \\
D(UNEMP) & $0.0326^{* *}$ & 0 & 5 & 26 \\
\hline
\end{tabular}

* signifikan pada $\alpha=0,01 * *$, signifikan pada $\alpha=0,05$, *** signifikan pada $\alpha=0,10$

Pemilihan model ARDL terbaik dengan kombinasi lag yang optimal, diseleksi berdasarkan akaike info criterion (AIC). Berdasarkan seleksi AIC, model ARDL terbaik bagi model penelitian ini adalah ARDL $(1,3,4,4)$. Nilai R-squared adjusted dan nilai R-Bar-squared model ARDL tersebut relatif tinggi, yaitu rata-rata sekitar 0.97 dan 0.93. Nilai R-squared adjusted sebesar 0.93 tersebut menyatakan bahwa 93\% variasi variabel terikat pengangguran mampu dijelaskan oleh masing-masing variabel bebas model ARDL yang terpilih. Hal tersebut merupakan indikasi awal bahwa model penelitian ini cukup baik untuk dianalisis. 
Tabel 2. Hasil Estimasi Jangka Pendek ARDL

\begin{tabular}{crrrr}
\hline Variable & Coefficient & Std. Error & t-Statistic & \multicolumn{1}{c}{ Prob.* } \\
\hline UNEMP(-1) & 0.686812 & 0.069735 & 9.848916 & 0,0000 \\
FDI & -0.00364 & 0.19874 & -0.01834 & 0.9858 \\
FDI(-1) & -0.03167 & 0.12152 & -0.26058 & 0.8010 \\
FDI(-2) & -0.06196 & 0.127212 & -0.48703 & 0.6393 \\
FDI(-3) & -0.30444 & 0.130813 & -2.32726 & 0.0484 \\
GROWTH & -0.04311 & 0.086383 & -0.49910 & 0.6311 \\
GROWTH(-1) & -0.08177 & 0.103511 & -0.78992 & 0.4523 \\
GROWTH(-2) & 0.091129 & 0.090807 & 1.003549 & 0.3450 \\
GROWTH(-3) & 0.005519 & 0.096393 & 0.057256 & 0.9557 \\
GROWTH(-4) & -0.26643 & 0.088796 & -3.00048 & 0.0171 \\
INFL & 0.000278 & 0.026101 & 0.010636 & 0.9918 \\
INFL(-1) & 0.001931 & 0.036215 & 0.053308 & 0.9588 \\
INFL(-2) & 0.033489 & 0.030078 & 1.113395 & 0.2979 \\
INFL(-3) & -0.022510 & 0.030538 & -0.73709 & 0.4821 \\
INFL(-4) & -0.085390 & 0.031101 & -2.74570 & 0.0252 \\
C & 12.86041 & 4.335153 & 2.966542 & 0.0180 \\
R-squared & 0.976146 & Mean dependent var & & 5.638083 \\
\hline
\end{tabular}

Dari hasil estimasi jangka pendek ARDL, terlihat bahwa variabel UNEMP(-1) memiliki nilai koefisien terbesar yaitu 0.68 , artinya faktor pengangguran tahun sebelumnya merupakan faktor dominan yang mempengaruhi tingkat pengangguran. Sebagai contoh, tingkat pengangguran satu tahun sebelumnya di Indonesia sebesar $1 \%$ akan menyebabkan pengangguran di Indonesia sebesar 68\%. Pengangguran tahun sebelumnya juga lebih berperan apabila dibandingkan dengan faktor inflasi, pertumbuhan ekonomi dan FDI, dimana koefisiennya relatif lebih besar apabila dibandingkan dengan koefisien faktor inflasi, pertumbuhan ekonomi, dan FDI. Nilai Koefisien inflasi -0,08 yang berarti peningkatan sebesar 1 persen akan menurunkan pengangguran sebesar sebesar $8 \%$ di tahun keempat. Koefisien pertumbuhan ekonomi sebesar -0,26 ini berarti jika terjadi peningkatan pertumbuhan ekonomi sebesar $1 \%$ akan menurunkan pengangguran sebesar sebesar $26 \%$ di tahun keempat. Sedangkan koefisien FDI sebesar -0,30 ini berarti jika peningkatan FDI yang masuk ke Indonesia sebesar $1 \%$ akan menurunkan pengangguran sebesar sebesar 30\% di tahun keempat.

Tabel 3. Hasil Estimasi Jangka Panjang ARDL

\begin{tabular}{crrrr}
\hline Variable & Coefficient & Std. Error & t-Statistic & \multicolumn{1}{c}{ Prob. } \\
\hline FDI & -1.28262 & 0.52952 & -2.42224 & 0.0417 \\
GROWTH & -0.94085 & 0.331236 & -2.84042 & 0.0218 \\
INFL & -0.23055 & 0.153753 & -1.49951 & 0.1721 \\
C & 41.06293 & 13.3141 & 3.084169 & 0.015 \\
\hline
\end{tabular}

Untuk dapat melakukan analisis ekonomi pengaruh inflasi, pertumbuhan ekonomi, dan FDI terhadap pengangguran, tidak cukup hanya berdasarkan informasi jangka pendek, namun perlu dianalisis pengaruhnya dalam jangka panjang. Dari hasil estimasi jangka panjang ARDL seperti terlihat pada Tabel 3, terlihat bahwa variabel FDI memiliki koefisien terbesar -1.28262 dan signifikan. Kemudian diikuti pertumbuhan ekonomi memiliki nilai koefisien -0.94085 dan signifikan, sedangkan inflasi koefisiennya relatif kecil yaitu -0.23055 namun tidak signifikan.

Pengujian kesesuaian model ARDL yang terpilih perlu dilakukan agar model penelitian yang dibentuk tidak melanggar kaidah-kaidah ekonometrika. Pengujian diagnosa model ARDL $(1,3,4,4)$ terutama akan dilakukan dengan pemeriksaan autokorelasi dan stabilitas model. Uji 
autokorelasi pada model ARDL $(1,3,4,4)$ akan menggunakan uji breusch-godfrey lagrange multiplier (BGLM), dengan hipotesis yang digunakan adalah sbb:

$\mathrm{H}_{0}$ : tidak terdapat autokorelasi pada residual model ARDL $(1,3,4,4)$

$\mathrm{H}_{1}$ : terdapat autokorelasi pada residual model ARDL $(1,3,4,4)$

Tabel 4. Hasil Uji Autokorelasi

\begin{tabular}{lcll}
\hline Breusch-Godfrey Serial Correlation LM Test: & \\
\hline F-statistic & 0.083728 & Prob. F(1,7) & 0.7807 \\
Obs*R-squared & 0.283676 & Prob. Chi-Square (7) & 0.5943 \\
\hline
\end{tabular}

Berdasarkan hasil pengolahan data sebagaimana pada Tabel 4 diketahui bahwa p-value statistik untuk uji BGLM tersebut adalah 0.5943. Hasil tersebut mengindikasikan bahwa pada tingkat kepercayaan 95\% null hypothesis tidak dapat ditolak, yang artinya tidak terdapat autokorelasi pada residual model ARDL $(1,3,4,4)$.

Untuk menguji stabilitas jangka panjang bersama dengan penyesuaian jangka pendek, maka digunakan CUSUM dan CUSUMQ (cumulative sum of recursive residuals). Jika plot CUSUM berada pada nilai kritis 5 persen atau tidak keluar dari garis batas atas dan batas bawah, maka estimasi dianggap stabil. Hal yang sama juga berlaku untuk CUSUMQ (cumulative sum of squares of recursive residuals). Berdasarkan hasil cusum test, model yang digunakan dalam penelitian ini layak karena cukup stabil dan valid untuk digunakan sebagai bahan analisis fenomena tersebut. Hasil CUSUM dan CUSUMQ test tersebut dapat dilihat pada Gambar 2.
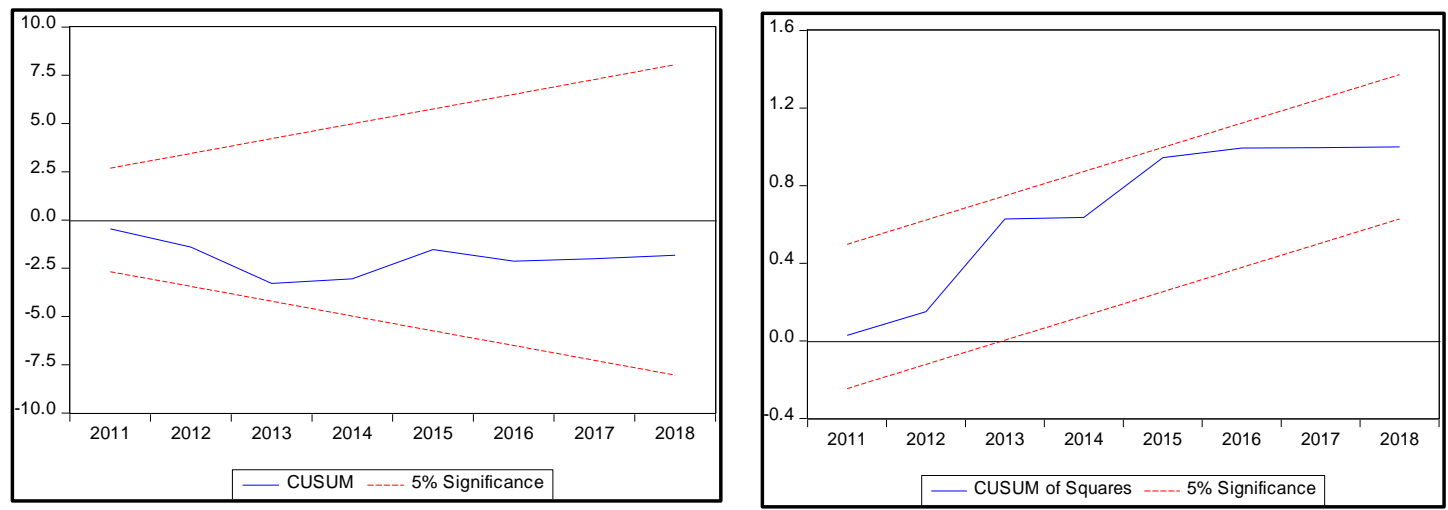

\section{Gambar 3. Uji Stabilitas Model Uji CUSUM dan Model Uji CUSUMQ}

Berdasarkan hasil Bounds Test untuk model ARDL $(1,3,4,4)$ pada tabel 4.5 , terlihat bahwa nilai $F$-statistic model adalah 6.855387 lebih besar dari nilai upper bound pada level 5\%, bahkan masih juga lebih besar dibandingkan dengan upper bound pada level 2,5\%. Hal ini membuktikan bahwa keempat variabel dalam penelitian ini yaitu pengangguran, penanaman modal asing langsung, inflasi dan pertumbuhan ekonomi terjadi kointegrasi dalam jangka panjang atau bisa dikatakan bahwa ketiga variabel tersebut bergerak Bersama-sama dalam jangka panjang. 
Tabel 5. Bounds Test Model ARDL

\begin{tabular}{lcccr}
\hline \multirow{2}{*}{$\begin{array}{l}\text { F-Bounds Test } \\
\text { Test Statistic }\end{array}$} & Value & Null Hypothesis: & \multicolumn{3}{c}{ No levels relationship } \\
\hline F-statistic & 6.855387 & $10 \%$ & 2.37 & I(0) \\
k & 3 & $5 \%$ & 2.79 & 3.2 \\
& & $2.5 \%$ & 3.15 & 4.07 \\
& & $1 \%$ & 3.65 & 4.66 \\
\hline
\end{tabular}

Hasil uji kointegrasi pada Tabel 6 diketahui bahwa nilai $\operatorname{CointEq}(-1)=-0.313190$ dan signifikan pada level 5\%, yang berarti terjadi kointegrasi jangka panjang dalam model ini. Koefisien CointEq selanjutnya akan digunakan untuk mengukur speed of adjustment yang merupakan kecepatan penyesuaian dalam merespon terjadinya perubahan. Nilai ECT atau CointEq valid jika koefisien bernilai negatif dengan probabilitas signifikan pada level 5\%. Pada penelitian ini, model ARDL $(1,3,4,4)$ telah memenuhi persyaratan validitas tersebut, sehingga dalam penelitian ini kita dapat menyimpulkan bahwa model akan menuju pada keseimbangan dengan kecepatan $31,31 \%$ per tahun.

Tabel 6. Dynamic Cointgration dan Speed of Adjustment

\begin{tabular}{lrrrr}
\hline & \multicolumn{2}{c}{ Cointegrating Form } & & \\
Variable & Coefficient & Std. Error & t-Statistic & \multicolumn{1}{c}{ Prob. } \\
\hline D(FDI) & -0.003640 & 0.077130 & -0.047250 & 0.9635 \\
D(FDI(-1)) & 0.366392 & 0.088130 & 4.157412 & 0.0032 \\
D(FDI(-2)) & 0.304436 & 0.089514 & 3.401005 & 0.0093 \\
D(GROWTH) & -0.043110 & 0.053089 & -0.812100 & 0.4402 \\
D(GROWTH(-1)) & 0.169783 & 0.065092 & 2.608365 & 0.0312 \\
D(GROWTH(-2)) & 0.260912 & 0.062671 & 4.163217 & 0.0032 \\
D(GROWTH(-3)) & 0.266432 & 0.062890 & 4.236469 & 0.0029 \\
D(INFL) & 0.000278 & 0.018256 & 0.015207 & 0.9882 \\
D(INFL(-1)) & 0.074415 & 0.024117 & 3.085552 & 0.0150 \\
D(INFL(-2)) & 0.107904 & 0.024432 & 4.416510 & 0.0022 \\
D(INFL(-3)) & 0.085394 & 0.022516 & 3.792659 & 0.0053 \\
CointEq(-1)* & -0.313190 & 0.043678 & -7.170450 & 0.0001 \\
\hline
\end{tabular}

Penelitian ini mencoba menemukan hubungan jangka pendek dan jangka panjang antara inflasi dan pengangguran di Indonesia dengan menguji keberadaan phillips curve, menggunakan model keynesian phillips curve yang baru. Hasilnya menunjukkan bahwa ada hubungan positif dan signifikan antara inflasi dan pengangguran dalam jangka pendek di Indonesia. Kondisi ini bisa terjadi karena sebagian besar inflasi yang terjadi di Indonesia bukan disebabkan oleh kenaikan permintaan agregat, tapi lebih desebabkan oleh penambahan jumlah uang beredar. Dalam jangka pendek hasil penelitian ini tidak sejalan dengan teori (Phillips, 1958) dimana peningkatan tingkat inflasi diterjemahkan menjadi penurunan tingkat pengangguran. Secara empiris hasil penelitian ini tidak sejalan dengan temuan Alisa (2015), Idenyi, Favour, Johnson, \& Thomas (2017), Kasseh, (2018) yang menyatakan bahwa hubungan antara inflasi dan pengangguran berbanding terbalik ada dalam jangka pendek.

Hubungan trade-off antara inflasi dan pengangguran menimbulkan dilema bagi perumus kebijakan, karena pengurangan pengangguran cenderung menyebabkan kenaikan tingkat inflasi dalam suatu ekonomi. Proses inflasi dan pengangguran merupakan bagian integral dari ekonomi pasar dan dianggap sebagai momok zaman modern ini. Namun sebagian besar ekonom setuju dengan pendapat bahwa dalam jangka pendek, ada hubungan terbalik antara pengangguran dan inflasi. Sedangkan untuk jangka panjang, hubungan seperti itu tidak ada. Kondisi ini sejalan 
dengan yang terjadi di Indonesia, karena berdasarkan data pergerakan inflasi di Indonesia setelah krisis moneter yang melanda perekonomian Indonesia hingga akhir tahun 2000 inflasi di Indonesia terus stabil dibawah 10 persen bahkan sering berada dibawah 5 persen pertahun.

Penelitian empiris ini menemukan bahwa pertumbuhan ekonomi memiliki koefisien negatif dan signifikan mempengaruhi penurunan pengangguran dalam jangka pendek maupun jangka panjang meskipun memerlukan lag yang cukup panjang yaitu 4 tahun. Kondisi ini terjadi karena sebagian besar pertumbuhan ekonomi Indonesia banyak didukung dari sektor moneter dibandingkan dengan sektor riil, sehingga pertumbuhan ekonomi yang terjadi tidak mampu menyerap banyak tenaga kerja sehingga perlu waktu yang lama untuk bisa mengurangi pengangguran. Hasil penelitian ini berhasil mengungkapkan bahwa berdasarkan data, pertumbuhan ekonomi memainkan peran yang sangat signifikan dalam mengurangi pengangguran di Indonesia. Temuan ini sekaligus menggambarkan bahwa hukum Okun berlaku di Indonesia walaupun dengan pengaruh yang beda dengan di Amerika Serikat. Secara empirik hasil penelitian ini sejalan dengan penemuan Hanusch (2013) tentang hukum Okun di negara-negara Asia; Nikolli (2014) di Albania; Ajie, Ani, \& Ameh (2017) di Negeria, Amor \& Hassine (2017) di Kerajaan Arab Saudi, serta Tenzin (2019) menggunakan model ARDL di Bhutan.

Berdasarkan temuan penelitian ini dapat menyimpulkan bahwa pertumbuhan ekonomi adalah variabel yang penting dalam hal mengurangi tingkat pengangguran di Indonesia. Studi ini mengungkapkan bahwa pertumbuhan ekonomi memainkan peran penting dalam mengurangi tingkat pengangguran. Namun, untuk mencapai tingkat pertumbuhan ekonomi yang tinggi dan mampu menciptakan lapangan kerja yang tinggi dan layak masih menjadi tantangan berat di Indonesia. Untuk mencapai hal tersebut, maka pengambil kebijakan dalam hal ini pemerintah harus menyediakan lingkungan investasi yang kondusif dengan menghilangkan kekakuan struktural yang ada dalam perekonomian untuk menarik investasi ke Indonesia. Investasi yang masuk diharapkan dapat membantu dan merangsang bisnis terutama bisnis yang mempekerjakan lebih banyak pekerja. Pemerintah perlu terus berupaya menciptakan lingkungan investasi yang kondusif misalnya dengan cara menyediakan pasokan listrik yang stabil, jalan yang baik untuk transportasi barang dan orang, sistem hukum fungsional, keamanan jiwa dan properti serta fasilitas infrastruktur yang memadai.

Tinjauan literatur selama ini menunjukkan bahwa tidak mudah untuk menggambarkan kesimpulan universal dan membentuk teori pada hubungan antara FDI dan pengangguran. Namun, ada beberapa karakteristik umum situasi ketika arus masuk FDI membawa hasil positif bagi pasar tenaga kerja terutama untuk negara-negara yang memiliki banyak tenaga kerja terampil. Ini berarti bahwa dalam kebijakan ekonomi jangka panjang perlu menciptakan kondisi yang baik untuk meningkatkan kualitas angkatan kerja. Hasil penelitian ini menemukan koefisien FDI memiliki pengaruh negatif dan signifikan terhadap penurunan pengangguran baik jangka panjang maupun jangka pendek di Indonesia walaupun masih memerlukan lag yang cukup lama yaitu 3 tahun. Kondisi ini terjadi karena sebagian besar FDI di Indonesia lebih pada sektor moneter dibandingkan yang bergerak di sektor riil. Temuan penelitian ini sejalan dengan temuan Irpan et al. (2016) yang menemukan peningkatan investasi asing langsung menyebabkan penurunan tingkat pengangguran di Malaysia. Stamatiou \& Dritsakis (2014) menemukan dalam jangka pendek dan jangka panjang terdapat peningkatan FDI yang mengurangi pengangguran. Strat et al. (2015) menemukan dalam kasus 4 dari 13 anggota UE terbaru-Hongaria, Malta, Bulgaria, dan Estonia, ada hubungan kausal antara FDI dan pengangguran. Penelitian ini juga sekaligus membuktikan bahwa kebijakan 
pemerintah selama ini yang terus mendorong masuknya modal asing ke Indonesia telah membuahkan hasil dengan terbukanya lapangan kerja untuk penduduk Indonesia sehingga mampu mengurangi tingkat pengangguran di Indonesia. Dari hasil penelitian ini juga dapat disimpulkan bahwa FDI di Indonesia telah mampu mengurangi pengangguran. Kondisi ini terutama merupakan konsekuensi dari investasi yang bersifat padat karya yang umumnya terdiri dari merger dan akuisisi perusahaan lokal.

\section{SIMPULAN DAN REKOMENDASI}

Penelitian ini bertujuan untuk melihat dinamika hubungan antara inflasi, pertumbuhan ekonomi, dan penanaman modal asing langsung terhadap pengangguran pada perekonomian Indonesia. Penelitian ini menggunakan pendekatan autoregressive distributed lag (ARDL) untuk mengolah data dari tahun 1991-2018 untuk melihat dinamika pengaruh jangka pendek dan pengaruh jangka panjang inflasi, pertumbuhan ekonomi, dan FDI terhadap pengangguran. Penelitian ini menemukan variabel inflasi dan pertumbuhan ekonomi serta penanaman modal asing mempunyai dinamika hubungan jangka pendek dan jangka panjang yang mempunyai kecepatan penyesuaian menuju keseimbangan yang cukup tinggi sampai 31,31\% tiap tahunnya. Semua kondisi ini menunjukkan bahwa variabel inflasi, pertumbuhan ekonomi dan penanaman modal asing langsung dalam pengambilan kebijakan makro ekonomi harus selalu memperhatikan dampaknya terhadap pengurangan pengangguran, karena keempat variabel tersebut saling berhubungan dan mempengaruhi.

Penelitian ini mengungkapkan bahwa inflasi dan pertumbuhan ekonomi serta penanaman modal asing memainkan peran penting dalam mengurangi tingkat pengangguran, maka pengambil kebijakan dalam hal ini pemerintah harus menyediakan lingkungan investasi yang kondusif dengan menghilangkan kekakuan struktural yang ada dalam perekonomian untuk menarik investasi baik investasi asing maupun investasi dalam negeri untuk mendorong pertumbuhan ekonomi dan menciptakan lapangan kerja. Disamping itu, pemerintah perlu terus meningkatkan tingkat pendidikan dan keterampilan tenaga kerja Indonesia melalui program pendidikan dan pelatihan lainnya yang diarahkan untuk meningkatkan inovasi dan produktivitas agar mampu terserap pada FDI yang masuk ke Indonesia untuk memperoleh upah yang lebih tinggi dan pada gilirannya akan membantu mengurangi tingkat pengangguran di Indonesia. Pemerintah juga bisa menggunakan kebijakan moneter untuk menjaga stabilitas pasokan uang beredar, karena penambahan jumlah uang beredar memiliki dampak positif pada peningkatan inflasi yang dapat mengganggu stabilitas harga di Indonesia. Bila kondisi ini berjalan dengan baik, maka pertumbuhan ekonomi dan aliran masuk FDI ke Indonesia diharapkan mampu membuka lapangan kerja yang banyak sehingga diharapkan bisa menjaga stabilitas harga agar bisa membantu mengurangi tingkat pengangguran di Indonesia.

Keterbatasan penelitian ini diantaranya, hanya menggunakan tiga variabel independen yaitu penanaman modal asing, pertumbuhan ekonomi, dan inflasi untuk menjelaskan pengangguran di Indonesia. Oleh karena itu penelitian kedepan perlu mempertimbangkan penambahan variabel lain yang diperkirakan mempengaruhi pengangguran, seperti keterbukaan perdagangan, tingkat upah, tingkat pendidikan dan sebagainya untuk memperoleh hasil yang lebih komprehensif. 


\section{DAFTAR PUSTAKA}

Adarkwa, S. (2017). The Impact of Economic Growth on Unemployment in Ghana: Which Economic Sector Matters Most? The International Journal of Business \& Management, 2321-8916. Retrieved from www.theijbm.com

Ajie, H. A., Ani, E. C., \& Ameh, O. E. (2017). An Examination of the Impact of Unemployment and Inflation on The Nigerian Economy: A Bounds Testing Approach. Journal of Public Policy and Administration, 1(1), 22-34. https://doi.org/10.11648/j.jppa.20170101.13

Al-Habees, M. A., \& Rumman, M. A. (2012). The Relationship between Unemployment and Economic Growth in Jordan and Some Arab Countries. World Applied Sciences Journal, 18(5), 673-680. https://doi.org/10.5829/idosi.wasj.2012.18.05.16712

Alisa, M. (2015). The Relationship between Inflation and Unemployment: A Theoretical Discussion about the Philips Curve. Journal of International Business and Economics, 3(2), 89-97. https://doi.org/10.15640/jibe.v3n2a7

Amor, M. Ben, \& Hassine, M. Ben. (2017). The Relationship between Unemployment and Economic Growth: Is Okun's Law Valid for The Saudi Arabia Case? International Journal of Economics and Business Research, 14(1), 44-60. https://doi.org/10.1504/IJEBR.2017.085553

Barens, I. (2011). To Use The Words of Keynes...": Olivier J. Blanchard on Keynes and The "Liquidity Trap. Darmstadt Discussion Papers in Economics.

Behera, J., \& Mishra, A. K. (2017). The Recent Inflation Crisis and Long-run Economic Growth in India: An Empirical Survey of Threshold Level of Inflation. South Asian Journal of Macroeconomics and Public Finance, 6(1), 105-132. https://doi.org/10.1177/2277978717695154

Bhattarai, K. (2016). Unemployment-Inflation Trade-Offs in OECD Countries. Economic Modelling, 58, 93-103. https://doi.org/10.1016/j.econmod.2016.05.007

Brozen, Y. (1958). Means for Maintaining Economic Stability. Journal of Farm Economics, 40(5), 1069. https://doi.org/10.2307/1234973

Davidson, C., \& Matusz, S. J. (2004). International Trade and Labor Markets: Theory, Evidence, and Policy Implications. In International Trade and Labor Markets: Theory, Evidence, and Policy Implications. https://doi.org/10.17848/9781417505920

Davidson, P. (1998). Post Keynesian Employment Analysis And The Macroeconomics Of Oecd Unemployment 1. The Post Keynesian Explanation of OECD Unemployment. The Economic Journal, 108, 817-831.

Djambaska, E., \& Lozanoska, A. (2015). Foreign Direct Investment and Unemployment Evidence From The Republic of Macedonia. International Journal of Economics, Commerce and Management United Kingdom, III(12), 73-85. https://doi.org/10.1111/j.14679701.2010.01324.x

Dutt, P., Mitra, D., \& Ranjan, P. (2009). International trade and unemployment: Theory and crossnational evidence. Journal of International Economics, 78(1), 32-44. https://doi.org/10.1016/j.jinteco.2009.02.005

Hanusch, M. (2013). Jobless Growth? Okun'S Law in East Asia. Journal of International $\begin{array}{llll}\text { Commerce, Economics and Policy, } & 4(03), & 1350014 .\end{array}$ https://doi.org/10.1142/s1793993313500142 
Idenyi, O., Favour, E.-O., Johnson, N., \& Thomas, O. (2017). Understanding the Relationship between Unemployment and Inflation in Nigeria. Advances in Research, 9(2), 1-12. https://doi.org/10.9734/air/2017/32218

ILO. (2019). Quick Guide on Interpreting The Unemployment. International Labour Organization.

Irpan, H. M., Saad, R. M., Nor, A. H. S. M., Noor. A. H. M., \& Ibrahim, N. (2016). Impact of Foreign Direct Investment on The Unemployment Rate in Malaysia. Journal of Physics: Conference Series, 710(1). https://doi.org/10.1088/1742-6596/710/1/012028

Johnny, N., Timipere, E. T., \& Krokeme, O. (2018). Impact of Foreign Direct Investment on Unemployment Rate in Nigeria (1980-2015). International Journal of Academic Research in Business and Social Sciences, 8(3). https://doi.org/10.6007/ijarbss/v8-i3/3905

Kasseh, P. A. (2018). The Relation between Inflation and Unemployment in the Gambia: Analysis of the Philips Curve. Journal of Global Economics, 6(02), 6-12. https://doi.org/10.4172/2375-4389.1000294

Keynes, J. M. (1936). The General Theory of Employment, Interest and Money. London: Harcourt., 31(196), 791. https://doi.org/10.2307/2278703

Kunle, A., S.O., O., \& Oluwafolakemi, F. O. (2014). Impact of Foreign Direct Investment on Nigeria Economic Growth. International Journal of Academic Research in Business and Social Sciences, 4(8), 234-242. https://doi.org/10.6007/ijarbss/v4-i8/1092

Kurtovic, S., Siljkovic, B., \& Milanovic, M. (2015). Long-Term Impact of Foreign Direct Investment on Reduction of Unemployment : Panel Data Analysis of The Western Balkans Countries. Journal of Applied Economics and Business Research, 5(2), 112-129.

Mitra, D., \& Ranjan, P. (2010). Offshoring and Unemployment: The Role of Search Frictions Labor Mobility. Journal of International Economics, 81(2), 219-229. https://doi.org/10.1016/j.jinteco.2010.04.001

Moore, M. P., \& Ranjan, P. (2005). Globalisation vs Skill-Biased Technological Change: Implications for Unemployment and Wage Inequality. Economic Journal, 115(503), 391422. https://doi.org/10.1111/j.1468-0297.2005.00994.x

Nikolli, E. (2014). Economic Growth and Unemployment Rate. Case of Albania. European Journal of Social Sciences Education and Research, 1(1), 217. https://doi.org/10.26417/ejser.v1i1.p217-227

Okun, A. M. (1962). Potential GNP: Its Measurement and Significance, Cowles Foundation Paper 190. Cowles Foundation, Yale University: New Haven, CT, USA.

Orji, A., Orji, O. A., \& Okafor, J. C. (2015). Inflation and Unemployment Nexus in Nigeria: Another Test of the Phillips Curve. Asian Economic and Financial Review, 5(5), 766-778. https://doi.org/10.18488/journal.aefr/2015.5.5/102.5.766.778

Parker, J. (2010). Models of Unemployment. Economics 314 Coursebook, (40), 86-87.

Phillips, A. W. (1958). The Relation between Unemployment and The Rate of Change of Money Wage Rates in the United Kingdom, 1861-1957. Economica, 25(100), 283. https://doi.org/10.2307/2550759

Pigou, A. C. (1934). Theory of Unemployment. Analysis (United Kingdom), 31(6), 177-186. https://doi.org/10.1093/analys/31.6.177 
Pinn, S. L. S., Ching, K. S., Kogid, M., Mulok, D., Mansur, K., \& Loganathan, N. (2011). Empirical Analysis of Employment and Foreign Direct Investment in Malaysia: An ARDL Bounds Testing Approach to Cointegration. Advances in Management and Applied Economics, 1(3), 77-91.

Quy, N. H. (2016). Relationship between Economic Growth, Unemployment and Poverty: Analysis at Provincial Level in Vietnam. International Journal of Economics and Finance, 8(12), 113. https://doi.org/10.5539/ijef.v8n12p113

Seth, A., John, M. A., \& Dalhatu, A. Y. (2018). The Impact of Unemployment on Economic Growth in Nigeria: An Application of Autoregressive Distributed Lag (ARDL) Bound Testing. Sumerianz Journal of Business Management and Marketing, 1(2), 37-46. https://doi.org/10.9790/0837-2211077481

Singh, D., \& Verma, N. (2016). Tradeoff between Inflation and Unemployment in The Short Run: A Case of the Indian Economy. International Finance and Banking, 3(1), 77. https://doi.org/10.5296/ifb.v3i1.9378

Stamatiou, P., \& Dritsakis, N. (2014). The Impact of Foreign Direct Investment on the Unemployment Rate and Economic Growth in Greece: A Time Series Analysis. International Work-Conference on Time Series Analysis (ITISE), 8(10), 4900-4906.

Strat, V. A., Davidescu, A., \& Paul, A. M. (2015). FDI and The Unemployment-A Causality Analysis for the Latest EU Members. Procedia Economics and Finance, 23, 635-643. https://doi.org/10.1016/s2212-5671(15)00448-7

Tegep, J., Suratman, E., \& Indra, S. (2019). The Failure of Foreign Direct Investment to Explain Unemployment Rate and The Mediating Role of Economic Growth and Minimum Wage. International Journal of Economics and Financial Issues, 9(2), 154-161.

Tenzin, U. (2019). The Nexus Among Economic Growth, Inflation and Unemployment in Bhutan. South Asia Economic Journal, 20(1), 94-105. https://doi.org/10.1177/1391561418822204

Wulandari, D., Utomo, S. H., Narmaditya, B. S., \& Kamaludin, M. (2019). Nexus between Inflation and Unemployment: Evidence from Indonesia. Journal of Asian Finance, Economics and Business, 6(2), 269-275. https://doi.org/10.13106/jafeb.2019.vol6.no2.269

Yolanda, Y. (2017). Analysis of Factors Affecting Inflation and Its Impact on Human Development Index and Poverty in Indonesia. European Research Studies Journal, 20(4), 38-56. https://doi.org/10.35808/ersj/873

Zeb, N., Qiang, F., \& Sharif, M. S. (2014). Foreign Direct Investment and Unemployment Reduction in Pakistan. International Journal of Economics and Research, 10-17. 